\title{
Continuities and discontinuities in the socio-environmental systems of the Atacama Desert during the last 13,000 years
}

\author{
Calogero M. Santoro ${ }^{\mathrm{a}, *}$, José M. Capriles ${ }^{\mathrm{b}}$, Eugenia M. Gayo ${ }^{\mathrm{c}}$, María Eugenia de Porras ${ }^{\mathrm{d}}$, \\ Antonio Maldonado ${ }^{\mathrm{e}}$, Vivien G. Standen ${ }^{\mathrm{f}}$, Claudio Latorre ${ }^{\mathrm{g}, \mathrm{h}}$, Victoria Castro ${ }^{\mathrm{i}}$, Dante Angelo ${ }^{\mathrm{f}}$, \\ Virginia McRostie $^{\mathrm{j}}$, Mauricio Uribe ${ }^{\mathrm{k}}$, Daniela Valenzuela ${ }^{\mathrm{i}}$, Paula C. Ugalde ${ }^{\mathrm{a}}$, Pablo A. Marquet ${ }^{1, \mathrm{~m}, \mathrm{n}, \mathrm{o}}$ \\ ${ }^{a}$ Laboratorio de Arqueología y Paleoambiente, Instituto de Alta Investigación, Universidad de Tarapacá, Antofagasta 1520, Arica, Chile \\ ${ }^{\mathrm{b}}$ Department of Anthropology, The Pennsylvania State University, University Park, PA 16802, USA \\ ${ }^{\mathrm{c}}$ Centro de Ciencia del Clima y la Resilencia (CR)2 \& Departamento de Oceanografía, Universidad de Concepción, Concepción, Chile \\ ${ }^{\text {d }}$ Centro de Estudios Avanzados de Zonas Áridas (CEAZA), Raúl Bitran 1305, La Serena, Chile \\ e Centro de Estudios Avanzados de Zonas Áridas (CEAZA), Universidad de La Serena, Raúl Bitran 1305, La Serena, Chile \\ ${ }^{\mathrm{f}}$ Departamento de Antropología, Universidad de Tarapacá, Cardenal Caro 348, Arica, Chile \\ ${ }^{\mathrm{g}}$ Departamento de Ecología y Laboratorio Internacional en Cambio Global (LINCGlobal), Pontificia Universidad Católica de Chile, Alameda 340, Santiago, Chile \\ ${ }^{\mathrm{h}}$ Instituto de Ecología y Biodiversidad (IEB), Santiago, Chile \\ ${ }^{\mathrm{i}}$ Departamento de Antropología, Facultad de Ciencias Sociales, Universidad Alberto Hurtado, Almirante Barroso $N^{\circ} 10$, Santiago, Chile

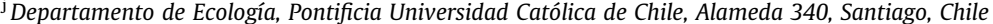 \\ ${ }^{\mathrm{k}}$ Departamento de Antropología, Universidad de Chile, Ignacio Carrera Pinto 1045, Santiago, Chile \\ ${ }^{1}$ Departamento de Ecología, Facultad de Ciencias Biológicas, Pontificia Universidad Católica de Chile, Santiago, Chile \\ ${ }^{\mathrm{m}}$ Laboratorio Internacional en Cambio Global (LINCGlobal), Pontificia Universidad Católica de Chile, Santiago, Chile \\ ${ }^{\mathrm{n}}$ Instituto de Ecología y Biodiversidad (IEB), Casilla 653, Santiago, Chile \\ ${ }^{\circ}$ The Santa Fe Institute, Santa Fe, NM 87501, USA
}

\section{A R T I C L E I N F O}

\section{Article history:}

Received 25 December 2015

Revision received 4 August 2016

Available online 31 August 2016

\section{Keywords:}

Atacama Desert

Pampa del Tamarugal

Climate change

Continuities and discontinuities

Human-environment interaction

Hyperarid environments

Water

\begin{abstract}
A B S T R A C T
Understanding how human societies interacted with environmental changes is a major goal of archaeology and other socio-natural sciences. In this paper, we assess the human-environment interactions in the Pampa del Tamarugal (PDT) basin of the Atacama Desert over the last 13,000 years. By relying on a socioenvironmental model that integrates ecosystem services with adaptive strategies, we review past climate changes, shifting environmental conditions, and the continuities and discontinuities in the nature and intensity of the human occupation of the PDT. As a result we highlight the importance of certain key resources such as water, an essential factor in the long-term trajectory of eco-historical change. Without water the outcome of human societies becomes hazardous.
\end{abstract}

(c) 2016 Elsevier Inc. All rights reserved.

\section{Introduction}

To a large extent, the history of humans is the history of a species in constant interaction with and mutual modification of its environment. Understanding how human societies interacted with

\footnotetext{
* Corresponding author.

E-mail addresses: calogero_santoro@yahoo.com (C.M. Santoro), jmcapriles@psu. edu (J.M. Capriles), emgayo@uc.cl (E.M. Gayo), meugenia.deporras@ceaza.cl (M.E. de Porras), amaldonado@ceaza.cl (A. Maldonado), vivien.standen@gmail.com (V.G. Standen), clatorre@bio.puc.cl (C. Latorre), vcastror53@gmail.com (V. Castro), dangeloz@gmail.com (D. Angelo), virginia.mcrostie@gmail.com (V. McRostie), mur@uchile.cl (M. Uribe), dani.valenzu@gmail.com (D. Valenzuela), arqueo.paulaugalde@gmail.com (P.C. Ugalde), pmarquet@bio.puc.cl (P.A. Marquet).
}

environmental changes is a major goal of archaeology, human ecology, and other socio-natural sciences. To this end, scholars have been concerned with the causes that led to the collapse or changes in social systems. The debate has confronted environmental causes and social factors. Recently, Roscoe (2014) has emphasized that "anthropological and archaeological research, with its integrative and universalist approach to social analysis" has the potential to improve our understanding of the long-term impacts of climate change (Costanza et al., 2007; Kintigh et al., 2014a,b; Roscoe, 2014). We add that combining both anthropologicalarchaeological data with ecological and paleoecological records can help characterize and explain past human practices within an eco-historical perspective as well as call attention to possible 
future ecological scenarios (Dearing et al., 2015, 2006; Van der Leeuw and Redman, 2002; Verstraeten, 2014).

Widespread desertification can affect large human populations and particularly socio-economically vulnerable communities and indigenous peoples, as it has been occurring in the African Sahel (Anderson et al., 2006; Geleta, 2014; Palmer and Smith, 2014). Alternatively, human practices can alter and transform the landscape considerably by means of several social, subsistence and ritual activities that produce, distribute and consume goods and services in order to maintain social and biological life. Today, there is growing consensus that major structural transformations in human societies, often documented as dramatic changes in the archaeological record such as regional abandonment, can be triggered by multifactorial internal and external factors (Aimers, 2007; Kohler et al., 2012; Rowland, 2008).

The goal of this paper is to present and discuss major trends in the long-term history of human-environment interactions in the Pampa del Tamarugal (PDT), located in the hyperarid core of the Atacama Desert in northern Chile. Using an eco-historical perspective, we focus on determining the social, economic, and technological, continuities and discontinuities that developed during key cycles of water availability, as inferred from archaeological and paleoenvironmental records during the entire span of human presence in the region.

\section{The Atacama Desert}

The Atacama Desert is a key region for examining how humans coped with climate change in environments considered extreme. Arid regions such as the Atacama cover more than a third of the planet and are very sensitive to climate change (Holmgren et al., 2006; Jimenez et al., 2011; Le Houerou, 1992; Ortega et al., 2012). Large variations in rainfall and temperature can drive large swings in productivity on inter-annual and even longer timescales (Noy-Meir, 1973). Like other subtropical arid regions (IPCC-AR4, 2007; Sheffield and Wood, 2008; Wang, 2005), the Atacama is predicted by regional models to become even more extreme (Minvielle and Garreaud, 2011; Urrutia and Vuille, 2009; Vuille, 2013), expecting substantial decreases in precipitation (20-30\%) and increases in temperature (rising up to $3^{\circ} \mathrm{C}$ ) and frequency of extreme hot events. In sum, the future is uncertain but past ecological and archaeological records are key sources of information to attempt to model how human societies respond to significant changes in resource availability.

Our specific study area is known as the Pampa del Tamarugal (PDT) basin and is situated in the hyper-arid core of the Atacama Desert (Fig. 1). The PDT basin is surrounded by five ecosystems: (a) the Pacific coast and Coastal Cordillera to the west, (b) the quebradas that drain the Andes to the east, (c) the Altiplano in the high Andes to the east, (d) the exorheic valleys to the north, and (e) the Loa river and the Salar de Atacama basin to the south. These ecosystems were part of the broader landscape of the groups that inhabited the PDT throughout time.

The little water available in the PDT occurs in seasonally activated streams and springs and depends, almost exclusively, on summer rainfall occurring in the western slope of the Andes (e.g. Houston, 2006; Magaritz et al., 1990; Muñoz et al., 2007). These events feed the desert ecosystem through underground aquifers and superficial runoff (Briner, 1985; Gajardo, 1994; Luebert and Pliscoff, 2006; Villagrán et al., 1999). Precipitation variability has had a strong impact on the availability of water resources for various ecosystems at different timescales, from the last 13 millennia to the last several centuries, as revealed by diverse array of proxy records (Latorre et al., 2003; Mujica et al., 2015; Nester et al., 2007; Quade et al., 2008).

\section{Theoretical framework}

Our general framework for understanding socio-environmental systems and their resulting dynamics is based on a variation of the conceptual model proposed by Marquet et al. (2012) to explain the emergence of socio-cultural complexity in early coastal societies of the Atacama Desert. Given that environmental and social systems are in constant interaction, our model focuses on the interaction between ecosystem services and adaptive strategies to describe socio-environmental continuities and discontinuities (Fig. 2). Specifically, the model integrates: (i) ecosystem services, defined as the available resources and energy provided by the environment and dependent on their own complex interactions (e.g., coastal upwelling drives marine productivity, and aquifer recharge increases freshwater availability), and (ii) adaptive strategies, which correspond to specific behavioral outcomes that together articulate human responses and strategies for appropriating, utilizing and producing the available ecosystem services (e.g. fishing, hunting, farming, exchange, and their combination). Adaptive strategies exist in the space of possibilities for human life defined by the supply of ecosystem services. Some adaptive strategies will fare better in this space, increasing in importance as a result of the interaction between demographic factors (the number of interacting individuals through social leaning), the impact of this number upon the generation of cumulative cultural evolution reflected for simplicity in technological and ideological changes, and their demographic feedbacks (Boyd et al., 2011; Henrich, 2008; Marquet et al., 2012). More formally, the basic components of an adaptive strategy are: (1) demography, including the population parameters that characterize human communities in terms of group size and growth trends (e.g., birth rates, death rates, fertility, etc.), (2) technology, which corresponds to the tools and procedures for extracting, processing and producing resources and energy (e.g., hunting, gathering and fishing instruments and techniques, agricultural terraces and irrigation canals, storage systems, etc.), and (3) ideology, which provides the cognitive and institutional framework that mediates human-environment interactions (e.g. resource sharing, group structure, division of labor, funerary practices, beliefs systems, etc.) and how humans interact among themselves. The nature and extent of ecosystem services available to human societies constrain specific adaptive strategies by means of the intervening components (Boyd and Richerson, 2005). Changes in one component will inevitably lead to alterations in other components, and thus upon the adaptive strategy itself, as well as on the type, rate, scale and intensity with which ecosystem services are used. Moreover, the availability and abundance of ecosystem services (caused by either internal or external factors) will impact the adaptive strategies by means of specific systemic responses in the intervening components. A given adaptive strategy can lead to the eventual under-exploitation, overexploitation or their sustainable use of ecosystem services, by means of regulating access to more resources or using them more efficiently (Ellis, 2015; Smith and Zeder, 2013), but this will depend upon the dominant ideology of the group, their technological means as well as their number. In other words, the nature of an adaptive strategy conditions both the demand of ecosystem services but also the generation of innovations (e.g. Henrich, 2004) to potentially solve the problems that this exploitation could generate, if the dominant ideology thinks it is important to do so.

By linking together social and environmental aspects within an adaptive framework, our model is compatible with other human ecology models that predict demographic and technological change in human societies (Henrich, 2004; Powell et al., 2009). Moreover, following Clarke's (1968) early archaeological modeling work, our systems approach is not deterministic but aims at pro- 


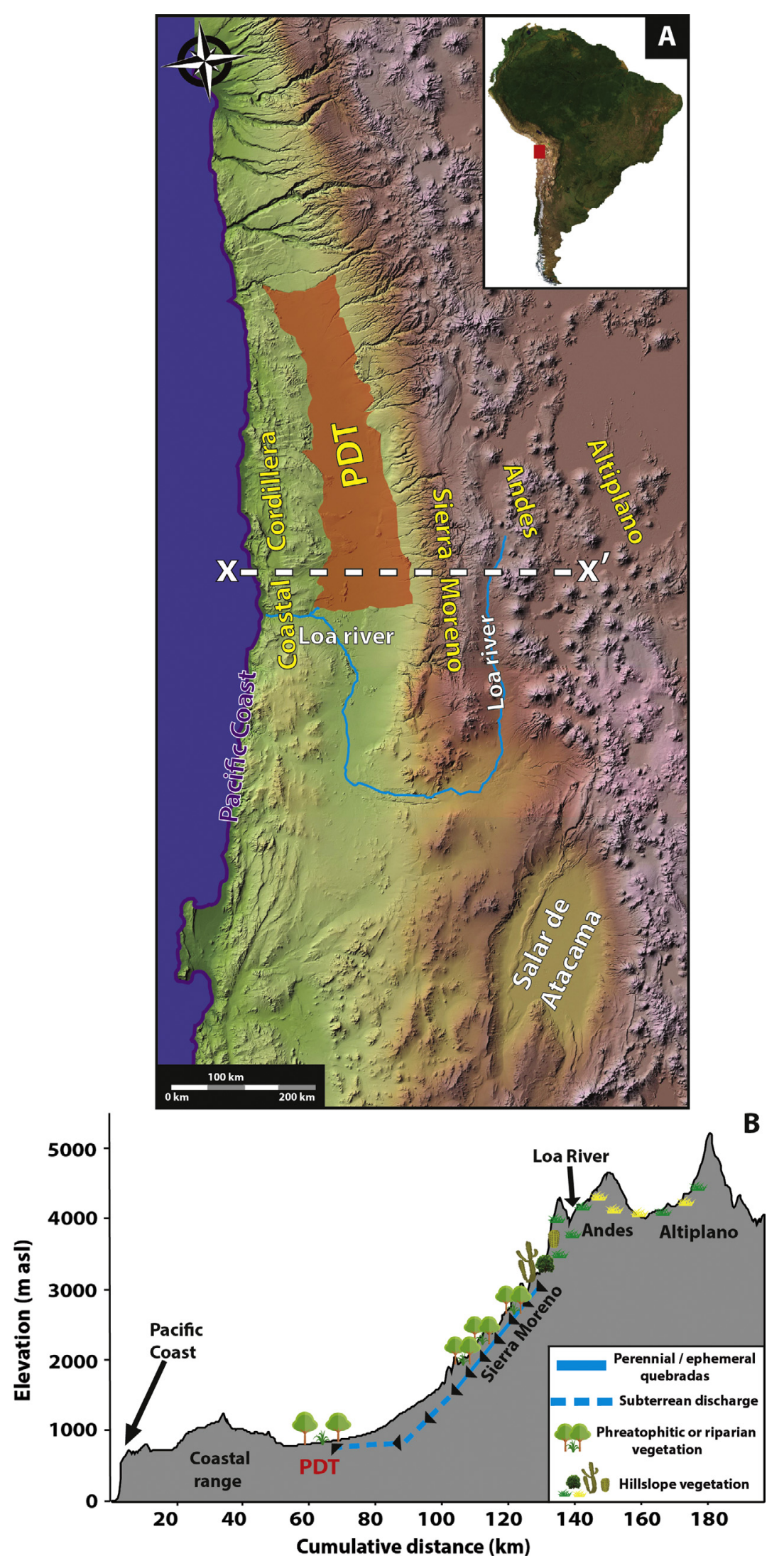

Fig. 1. Study area showing (A) the extent of the Pampa del Tamarugal (PDT) within the Atacama Desert. The dashed line (X-X') describes the topographic profile with major topographic and vegetation units (shown in B). 


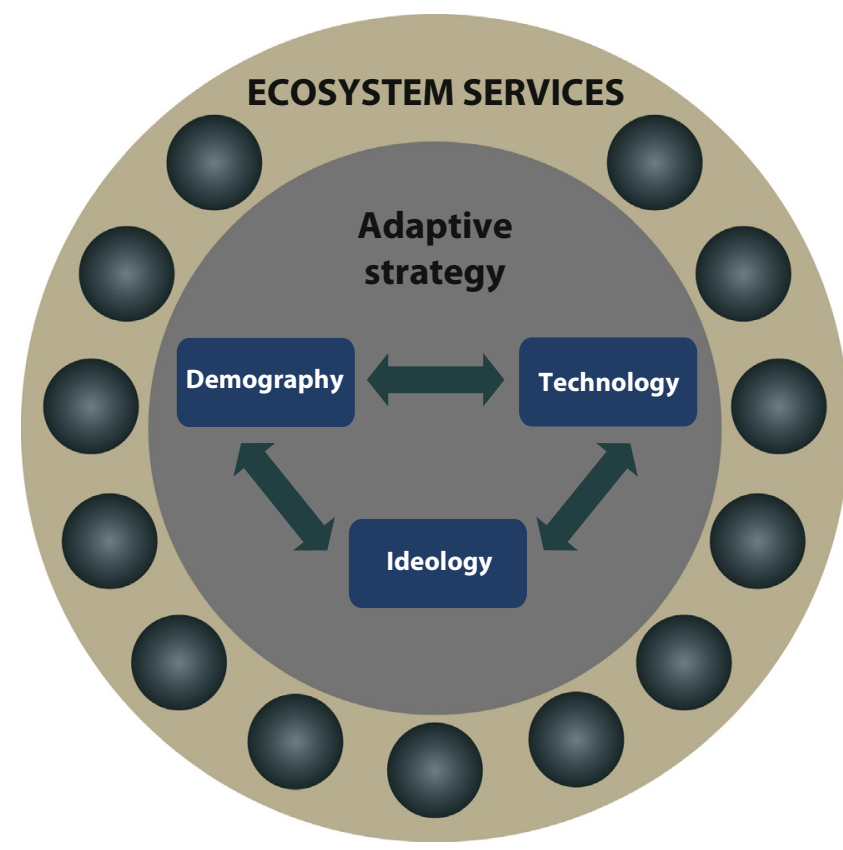

Fig. 2. Graphical depiction of our theoretical framework to understand the emergence of adaptive strategies. First, adaptive strategies emerge in the space of ecosystem services, and capitalize on particular resources provided by the ecosystem. These strategies involve the interaction between demographic, technological and ideological factors that jointly modulate the demand and use of the services provided by ecosystems. In a given ecosystem, different strategies are likely but only one become dominant, at least in a given time frame.

viding a conceptual framework to understand the emergence of adaptive strategies understood as a way of being in the world for a particular group of humans in the space of ecosystem services (Millennium Ecosystem Assessment, 2005) or the services that ecosystems provide to sustain human life.

In the context of this framework, social continuities and discontinuities are seen as a result of the interaction between a given adaptive strategy and the environment wherein it is embedded. An example of the latter is the collapse of local farming communities in the Samaca basin of southern Peru (Beresford-Jones et al., 2009) as a consequence of large flash floods linked to intensive ENSO events and enhanced by the overexploitation of the local Prosopis forests, that previously ameliorated the impact of flooding. Moreover, since our case study corresponds to the Atacama Desert, the most critical resource for engaging and transforming the socioenvironmental systems was water (Núñez and Grosjean, 2003; Núñez et al., 2010).

Based on the modern relationship between hydroclimate, coastal upwelling of nutrient-rich cold waters, and the ecosystem productivity of the Atacama Desert and the adjacent Altiplano (Jaksic, 2001; Muñoz and Bonacic, 2006; Squeo et al., 2006; Thiel et al., 2007; Washington-Allen et al., 2008), we could expect changes in past availability of ecosystem services as well as proportional adaptive responses throughout a series of hypothetical cascade effects (Fig. 3) (Gayo et al., 2014; Williams et al., 2008). Since environmental variability of terrestrial and marine systems from the western Andean slope is driven by the same mechanisms (i.e. El Niño Southern Oscillation), an orchestrated demographic response (in timing or direction) should be detected in both areas. That is, enhanced (weaken) summer rainfalls above $2200 \mathrm{~m}$ above sea level (asl) in the western Andes can led to positive (negative) anomalies in hydrological patterns (e.g. increased runoff, groundwater discharge) in the PDT basin, which in turn amplified (reduced) the extension of fertile oasis for human activities across the Atacama inland and Altiplano. Similarly, enhanced (weakened) upwelling of cold nutrient-rich waters along western coast of South America driven by strong (weak) southerly winds can result in amplified (reduced) bioproductivity of the coastal ecosystems along the Atacama Desert littoral.

The long-term population dynamics of the region has been recently reconstructed using summed probabilities of calibrated radiocarbon dates from coastal and inland archaeological sites (Gayo et al., 2015; Williams et al., 2008). Here we use this sequence (Fig. 4) to make inferences about population trends over the past 14,000 years. Moreover, under our working cascade effect hypothesis, we expect low (high) probability values in the summed probability distribution during intervals of reduced (enhanced) bioproductivity in terrestrial and coastal ecosystems.

Much of the long-term population dynamic in the Atacama Desert arises from coastal and inland paleodemographic reconstructions based on the distribution of summed probabilities of archaeological radiocarbon dates. Specifically, we considered unbiased inferences of population trends reconstructed by Gayo et al. (2015) and Williams et al. (2008) for the western Andean slope over the past 13,000 years. Hence, under our working cascade effect hypothesis, we could expect low (high) probability values in the summed probability plots of radiocarbon data through intervals of reduced (enhanced) bioproductivity in terrestrial and coastal ecosystems. We agree with Timpson et al. (2014) that the invalidation of the method arisen from a simulated historical time-series (last 800 years) is inadequate because it spans the most problematic interval for any calibration curve (see the Introduction section for further details). These authors also stress the use of the trimming technique to hamper the impact of such spurious calibration effects in long-term reconstructions, which was applied to our reconstruction (see Gayo et al., 2015).

\section{The first human occupations in the Atacama (13-10 ka)}

During the glacial-interglacial transition at least two extended periods of increased rainfall, together termed the Central Andean Pluvial Event (CAPE I: from 17.5 to $14 \mathrm{ka}$ and CAPE II: from 13 to $10 \mathrm{ka}$ ) (Quade et al., 2008), dramatically accelerated the regional hydrological cycle. Both events created vast 'paleolakes' in the Uyuni basin (Placzek et al., 2009, 2006; Sylvestre et al., 1999) and other smaller basins in the Altiplano (Giralt et al., 2008; Grosjean et al., 1995, 2001; Moreno et al., 2009), and enhanced groundwater discharge rates toward the Pacific lowlands (Quade et al., 2008; Rech et al., 2003, 2001, 2002). Such hydroclimatic conditions affected the latitudinal and altitudinal distribution of many plant species in northern Chile as evidenced by downslope displacement of the Subnival and High Andean steppe vegetation belts about $1000 \mathrm{~m}$ and the expansion of the Puna belt and Pre-Puna annual plants into the absolute desert (Latorre et al., 2006; Maldonado et al., 2005; Placzek et al., 2009; Quade et al., 2008).

In the PDT, CAPE is locally expressed as amplified events that brought about major changes in the availability of ecosystem services. For instance, riparian/wetland ecosystems (mostly composed by Escallonia angustifolia, Schinus molle, Prosopis and Distichlis spicata communities) expanded into what is now the hyperarid core of the Atacama in association with increased perennial stream discharge and groundwater tables (Gayo et al., 2012a; Nester et al., 2007). These habitats housed small (rodents and birds) and large-sized (camelids) fauna. The CAPE periods of "bonanza" made the PDT an attractive habitat for hunter-gatherers, and archaeological evidence suggests that they occupied the region by $13 \mathrm{ka}$ and perhaps even earlier. In fact, a number of human 


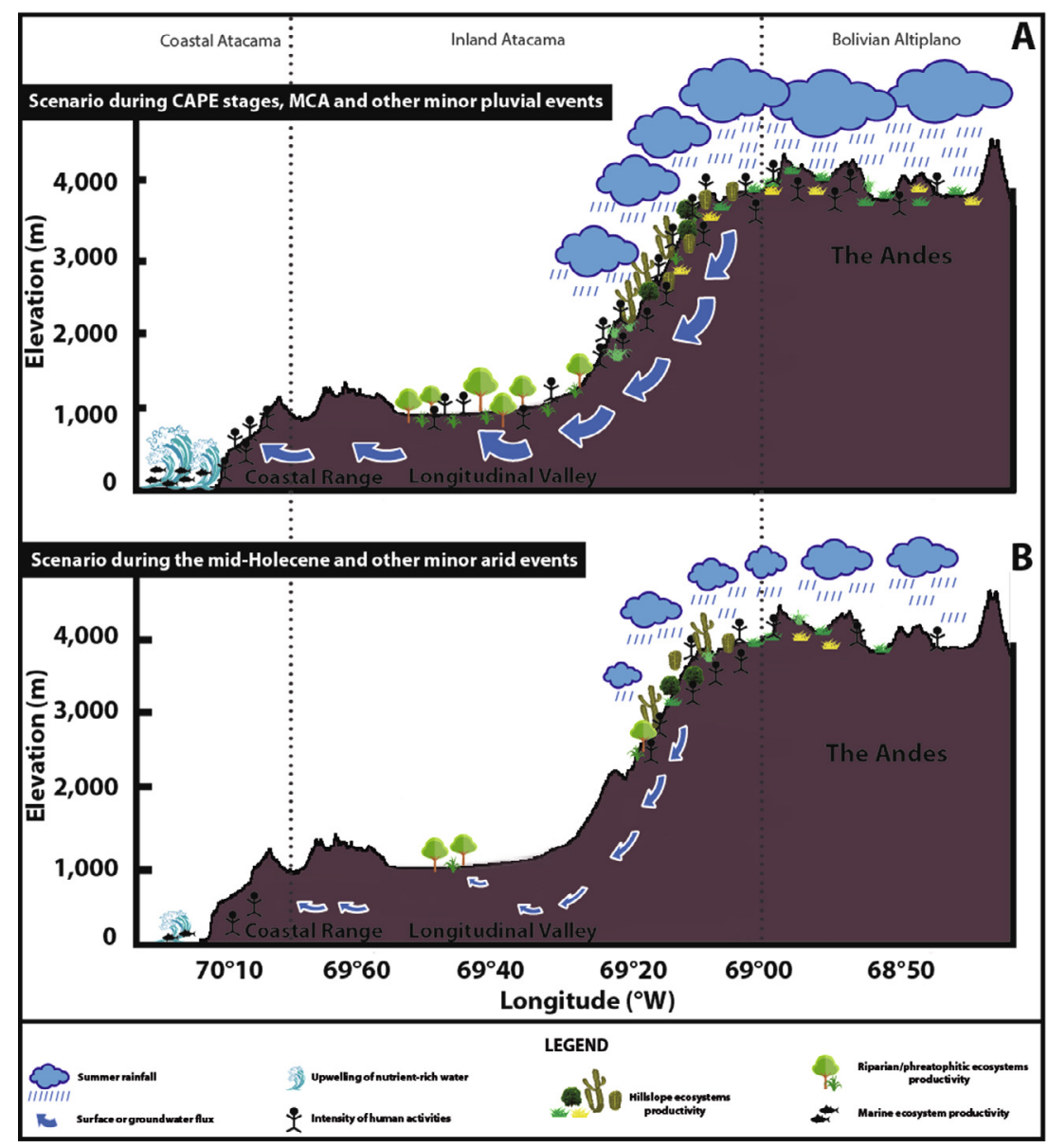

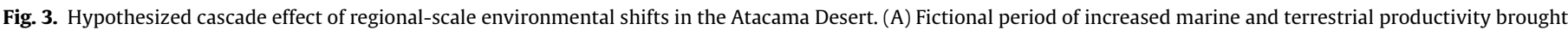

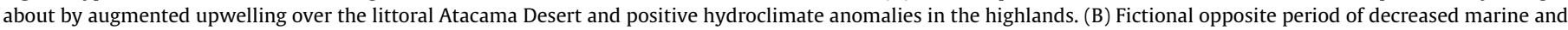
inland productivity.

occupations dated between 12.8 and 11.7 ka have been documented in the PDT (Latorre et al., 2013; Santoro et al., 2011a). Excavations at Quebrada Maní 12 (QM12) yielded evidence of a diverse cultural assemblage consisting of abundant lithic tools and debitage, burned and cut bones, small marine gastropods selected for adornment, red pigments possibly for hide processing and cosmetic use, and processed plant and animal fibers (Latorre et al., 2013). The camp, which included features such as prepared fireplaces, was intermittently occupied possibly as a residential base (Latorre et al., 2013; Núñez et al., 2016; Santoro et al., 2011a, 2011b; Ugalde et al., 2012). Our ongoing research in three other contemporaneous open camps, separated by no more than $30 \mathrm{~km}$, suggests that QM12 was part of a complex adaptive system of hunter-gatherers that was successfully taking advantage of the increased ecosystem services available in the PDT during the CAPE II. These sites are also associated with paleowetland deposits including well-preserved tree trunks and other plant remains.

The earliest coastal settlements are situated both to the north and the south of the PDT and include Quebrada Jaguay, Quebrada Tacaguay, La Chimba, and Taltal (deFrance and Umire, 2004; Jackson et al., 2011; Keefer et al., 1998; Llagostera et al., 1997; Salazar et al., 2015, 2011; Sandweiss et al., 1998). Evidence from QM12 demonstrates that the hunter-gatherers that occupied the PDT during the CAPE II maintained contact with the coast, so it is entirely possible that Holocene marine transgressions obliterated late Pleistocene coastal camps.

\section{Socio-environmental discontinuity during the early and middle Holocene (10-3 ka)}

So far, the PDT has revealed more substantial evidence for early and sustained peopling of the region than other adjacent (and potentially more attractive) ecosystems such as the coast and the highlands (but see Capriles et al., 2016). Nevertheless, after the CAPE II, exacerbated arid conditions prevailed between 10 and $3 \mathrm{ka}$, in the Atacama Desert, which underwent a severe and protracted period of aridity and ecological stress (Fig. 4A). The intensity, geographical extent, and timing of this arid phase is a matter of discussion (Betancourt et al., 2000; Grosjean et al., 2003; Latorre et al., 2003; Ledru et al., 2013; Maldonado et al., 2005). In the PDT, extreme arid conditions prevailed and drastically reduced the availability of ecosystem services (Betancourt et al., 2000; Latorre et al., 2003; Ledru et al., 2013; Rech et al., 2002).

Under new climatic conditions, archaeological data suggest that important transformations occurred in settlement patterns and cultural behavior, producing a phenomenon of socioenvironmental discontinuity that has been conceptualized as the "silencio arqueológico" (archaeological silence) (Núñez et al., 2002, 2013). To cope with long periods of widespread environmental uncertainty and reduction of ecosystem services imposed by the prolonged and intense aridity, people either abandoned the region, possibly migrating towards the coast and highlands (see below), or 


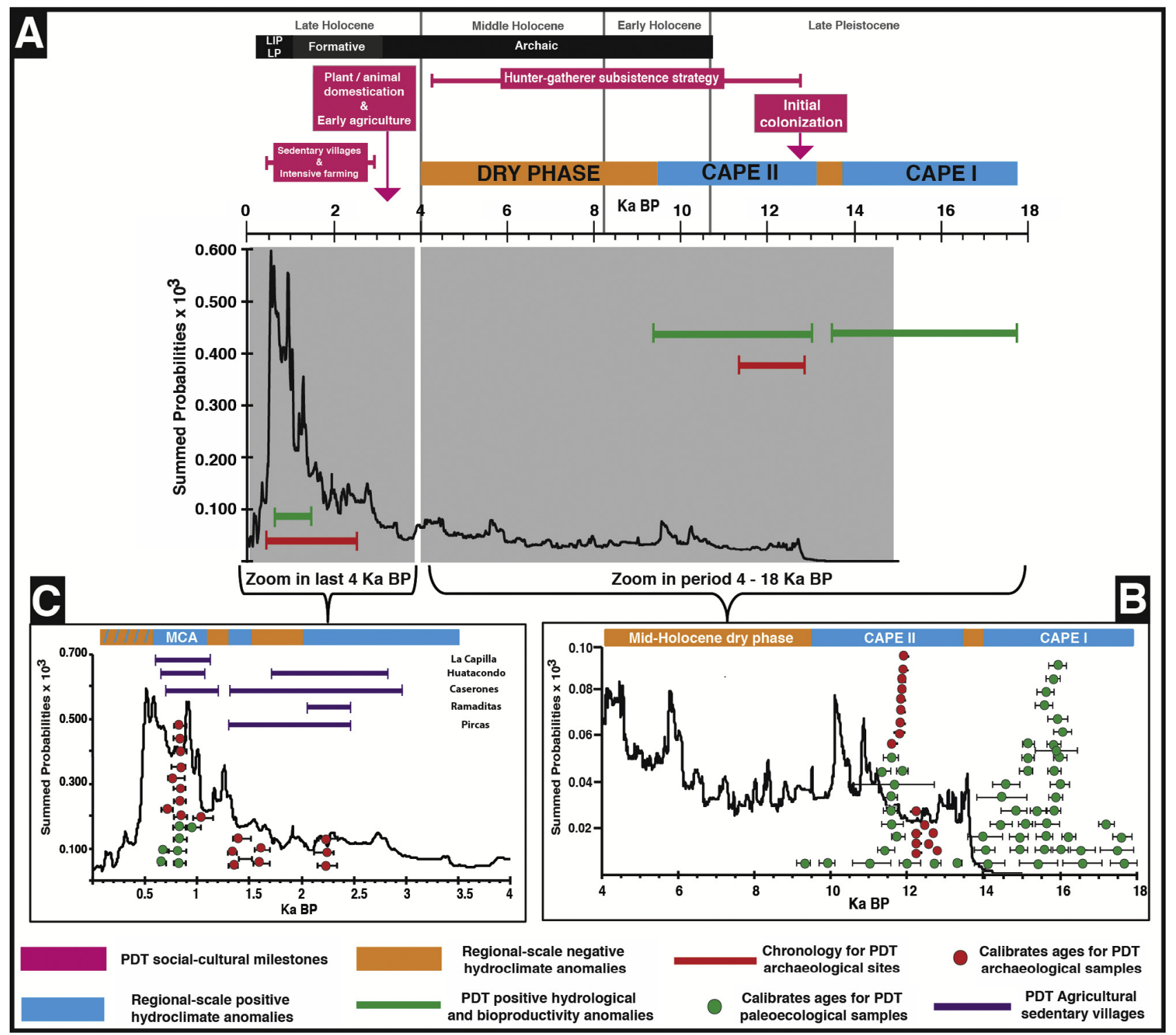

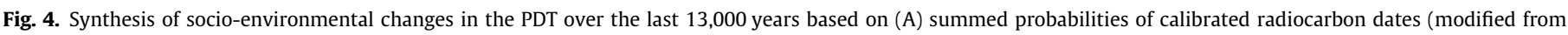

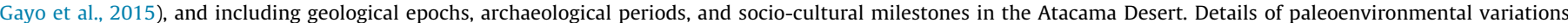

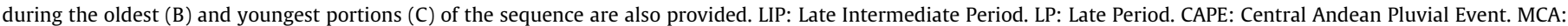
Medieval Climate Anomaly.

settled near the few and very localized sources of permanent water (i.e., "ecological refuges") (Aldenderfer, 1988, 1998; Aldenderfer and Flores Blanco, 2011; Cartajena, 2013; de Souza, 2004; Grosjean et al., 2005, 1997, 2007; Núñez et al., 2013, 1995; Núñez and Grosjean, 1994; Santoro et al., 2016; Santoro and Núñez, 1987).

A possible location for ecological refuges includes the quebradas of Sapiga (the northern drainage of the PDT) and Tiliviche, where the sites of Aragón and Tiliviche 1 are situated respectively (Núñez, 1986; Núñez and Zlatar, 1976). The occupation of these sites begins ca. $9.5 \mathrm{ka}$ and continues, albeit discontinuously, throughout the early and middle Holocene, containing both inland and marine food remains, suggesting that the locally available ecosystem services had to be complemented by coastal resources.

\subsection{What happened along the coast?}

In contrast to the PDT, the coast shows a strong sequence of continuous occupation beginning approximately 9 ka (Marquet et al., 2012). The coastal settlements found at several locations such as Punta Pichalo, Punta Patillo, and Caleta Huelén show the development of a specialized technology focused on the exploitation of marine resources including abundant hooks, harpoons, fishnets, etc. (Andrade et al., 2016; Bird, 1943; Standen et al., 2004). Between 7 and 4 ka coastal settlements became more abundant although with regional variation possibly tied to fresh water availability and marine upwelling. Maritime communities increased their technological specialization by creating a full range of tools that included watercrafts, harpoons for hunting marine mammals, hooks made of cactus spines and shells, sea lion ribs (chope) for collecting and processing gastropods, and plant fiber bags for collecting shellfish (Andrade et al., 2016; Olguín et al., 2014; Standen and Arriaza, 2016).

The coastal peoples also introduced complex ideological innovations, which included sophisticated procedures to transform and preserve their dead by means of artificial mummification (Arriaza et al., 2005; Standen, 1997). The way that corpses were intervened involved the selection, procurement, and transforma- 
tion of different raw materials (i.e., clay, wood, vegetable fiber, pigments, animal skins and human hair) (Arriaza, 1995a,b; Llagostera, 2003; Rivera, 1995; Standen, 1997). Artificial mummification possibly arose within a dynamic process that involved population growth related to increased and stable ecosystem services (i.e., high marine productivity and water availability) and an increase of naturally mummified remains (Marquet et al., 2012).

\subsection{Colonization of the high Andes}

A series of rodent middens collected at $21^{\circ} \mathrm{S}$ and above $4000 \mathrm{~m}$ asl suggests that during the early and middle Holocene, the Altiplano east of the PDT was comparatively more productive (de Porras et al., 2015). Archaeological data supports that, although preceded by exploratory and logistical incursions, huntergatherers were recurrently occupying the highlands after $10 \mathrm{ka}$ (Albarracin-Jordan and Capriles, 2011; Capriles and AlbarracinJordan, 2013; Herrera et al., 2015; Moreno et al., 2009; Osorio et al., 2011). Moreover, archaeological evidence supports cultural connections between the first inhabitants of the PDT and the later extensive settlement of the Altiplano. For instance, Patapatane projectile points, which may have originated in the PDT, became widespread in the Andean highlands as people improved and adapted to a hunting and gathering social system in the higher but more vegetated terrain. The distribution of these artifacts is also wider and persisted longer in time (Capriles et al., 2011; Klink and Aldenderfer, 2005; Maldonado and Uribe, 2015; Núñez and Santoro, 1990; Santoro, 1989; Santoro and Núñez, 1987). However, it is worth noting that the factor that caused the hyper aridity in the PDT also caused decreased precipitation in the highlands (Gayo et al., 2012b; Nester et al., 2007). In Antofagasta de la Sierra in northwest Argentina, Pintar (2014) has suggested less vulnerable environments above $4000 \mathrm{~m}$ asl attracted people during a dry period beginning around 8000 years cal ago. Similarly, in the eastern Bolivian Altiplano (16S) Ledru et al. (2013) have hypothesized that "ecological refuges" were key for sustaining hunter-gatherers in the highlands ( $\sim 3750 \mathrm{~m}$ asl) during the arid middle Holocene.

\section{The return to the PDT during the late Holocene (3-0.5 ka)}

After 3 ka major socio-environmental changes are observed in the archaeological record of the south central Andes, which have been related to an increasingly humid climatic regime (Baker and Fritz, 2015; Baker et al., 2001; Binford et al., 1997; Fritz et al., 2012; Pintar, 2014). The changes continued to develop over the next millennia causing the increase of available ecosystem services within the Atacama Desert. Paleoecological and archaeological archives support that wetter conditions in both superficial and groundwater gradually increased in the PDT during the late Holocene (Gayo et al., 2012b; Maldonado and Uribe, 2015). Three positive moisture anomalies ( 2.5-2.0, 1.6-1.3, and 1.1-0.68 ka) increased local phreatic levels and stimulated the natural vegetation coverage of non/woody and woody taxa (for instance Prosopis cf. strombocarpa) across the PDT. The forests certainly created distinct fertile landscapes that favored hunting and gathering as well as silvo-agropastoralist systems. In this regard, some algarrobo species with edible pods (i.e. Prosopis alba, P. flexuosa) that occur for the first time during this period could have been introduced from the eastern Andes (McRostie, 2013, 2014). The same might be true of the agricultural complex that included Arachis hypogaea, Chenopodium quinoa, Lagenaria, Phaseolus lunatus, P. vulgaris, and Zea mays (García et al., 2014) as well as plants introduced for foraging purposes (e.g., Euphorbia amandi, Junellia sp.) (Gayo et al., 2012b).

\subsection{The Formative Period in the PDT}

This new phase of "bonanza" is coeval with the Formative Period $(2.5-1.5 \mathrm{ka})$, which in the PDT is characterized by the emergence of complex communities that engaged in dynamic scenarios for social congregation, experimentation, and innovation. Large dispersed and concentrated villages with monumental public spaces founded during this period include: Pircas, Caserones, Ramaditas, Guatacondo, and La Capilla, among others (Adán et al., 2013; Cabello and Gallardo, 2014; Urbina et al., 2012; Uribe, 2006b, 2009; Uribe and Vidal, 2012) (Fig. 4C). A wide range of economic, social and technological innovative arrangements were added to the traditional hunting and gathering systems. The village communities of the PDT also engaged in textile production, wood and shellfish carving, pottery and basketry production, among other manufactures, indicating a growing demand for everyday consumption and public exposure. A landscape of social effervescence seems to have emerged within the PDT villages and its associated ceremonial places such as the cemetery Tarapacá 40 (Uribe et al., 2015). Population size in the PDT increased during this period (Fig. 4, Gayo et al., 2015) and local communities developed sophisticated technologies for managing surface water including the construction of water dams, irrigation canals, welldrained cultivation plots, and wild resources (González-Silvestre et al., 2013; McRostie, 2014; Núñez and Santoro, 2011; Rivera, 2005; Rozas, 2014; Urbina et al., 2012; Vidal et al., 2015).

Regional hydroclimate was still variable during the late Holocene and droughts of diverse duration occurred. Important gaps in the paleoecological record during $2.0-1.6$ and $1.3-1.1 \mathrm{ka}$ at the PDT suggest that these aridity events were characterized by reduced productivity brought about by negative hydrological budgets (Gayo et al., 2012b; Fig. 4C). Although the effects of these short-term droughts caused population relocation and disaggregation, the adaptive strategies were successful enough to sustain socio-cultural continuity.

\subsection{Socio-environmental systems during late prehistoric period}

Late Holocene droughts detected in the PDT could have provoked abandonment and migration in agricultural villages such as Ramaditas and Guatacondo. Likely, these extreme events resulted in massive population migrations to upstream areas and the establishment of new settlements around sectors where water resources were much more abundant and predictable (Maldonado and Uribe, 2015). The observed shift of villages towards the highlands or "sierra" during the Late Intermediate and Late periods (1-0.6 ka) was possibly caused both by sociopolitical turmoil as well as climatic deterioration (Uribe, 2006a; Uribe et al., 2007; Zori and Brant, 2012). Multiple communities in higher oases, quebradas, sierra, and Altiplano established new systems of agriculture (terraces and irrigation canals), defensive arrangements, and land management within their increasingly circumscribed territories. For instance, the inhabitants of Tarapacá Viejo, one of these higher valley communities, chose diverse risk reduction strategies to minimize both shortage of resources and conflict induced-risk (i.e., increased trade, agricultural diversification and intensification, farming in strategic enclaves, building defensive features, and ritual exchange expressed in rock art) (Zori and Brant, 2012).

During the last millennium, environmental conditions in the PDT were strongly influenced by the Medieval Climate Anomaly (1.1-0.6 ka) (Holmgren et al., 2008; Latorre et al., 2006, 2002; Maldonado et al., 2005; Morales et al., 2012; Mujica et al., 2015). Regional-scale amplified water budgets in the highlands produced positive hydrological balances that increased recharge rates of Andean aquifers and episodic flashfloods in the PDT (Rech, 2001; Rech et al., 2003, 2001). Important population aggregations sup- 
ported by farming, herding, and foraging developed in highland sierra valleys (above $2400 \mathrm{~m}$ ) such as Camiña and Mamiña (Adán and Urbina, 2010; Maldonado and Uribe, 2015; Mendez-Quiroz and Uribe, 2010; Pestle et al., 2015; Urbina and Adán, 2006; Uribe et al., 2007). At the same time, the mostly abandoned PDT, was transformed in an inter-nodal territory crossed by trains of llama caravans communicating the highlands with the coast, and only, occasionally used opportunistically by farmers following flashfloods episodes that inundated sections that made fields temporarily productive (Briones et al., 2005).

Archaeological evidence suggests that mining was one of the regional economic activities that developed during the late prehistoric period in the Atacama Desert. Although smelting and mineral extraction took place in Tarapacá since at least $3 \mathrm{ka}$, mining tasks were tightly connected to the production of prestige goods and tied to inter-regional trade networks (Zori et al., 2013). During the apogee of the Inca State (0.5-0.4 ka), copper and silver mining became important and the scale and organization of mining exploitation and metal production was restructured (Zori and Tropper, 2010). Later, as the economic emphasis of the Andean region was restructured by silver mining, some traditional activities (i.e., agriculture, herding and foraging) became gradually abandoned or deteriorated. Silver was a highly profitable resource in economic terms, as well as a metaphor for wealth, access to power and enhancement of social status (Castro et al., 2012; Gluzman, 2007).

\section{Mining and capitalism in the Desert at the dawn of the Anthropocene (0.5-0 ka)}

Arid conditions prevailed in the region over the last five centuries (Latorre et al., 2003; Placzek et al., 2001), intercalated by short-lived wet pulses (Christie, 2009; Holmgren et al., 2008; Kuentz, 2012; Morales et al., 2012; Mujica et al., 2015). Nevertheless, the Spanish conquest of the Andes brought new political, technological, demographic, and land use conditions that drastically changed the socio-environmental systems of the Atacama Desert. Demographically, strong transformations occurred, especially along the Pacific Coast, where the Spaniards settled their first colonial cities. This socio-environmental discontinuity persisted until the second part of the 19th century, when an extensive reoccupation of the Atacama Desert took place, as part of the boom in the exploitation of the saltpeter. Unlike previous periods, the colonial occupation of the PDT no longer responded simply to subsistence strategies and socio-environmental transformations occurred despite the desert's physical constrains. As such, the consequences of the new social and political strategies prompted by the new economic model were significant and its impact in the desert landscape is still visible today.

During colonial times, taking advantage of socio-political conditions already established by the Inca conquest, the Spaniards focused - and intensified - the exploitation of some of the desert's mining resources (Zori and Tropper, 2010, 2013). Throughout colonial and, mainly during republican times, mining became increasingly significant for the regional and burgeoning global market economy. With the advent of the anthropocene brought by the industrial revolution, the demands for the mining resources, as well as the technology employed for acquiring them, marked a clear distinction in the dynamics of the human-environmental relationships (Crutzen, 2002).

One of the major consequences of the extractive mentality that soon characterized the modern economy imposed by market capitalism is related to the environmental changes occurred in the last century. By rendering different territories as marginal and empty spaces, this particular narrative was part of the colonial gaze that legitimated the occupation of places. This new way to conceive the Atacama historically involved the displacement of their inhabitants and the imposition of a rationale of progress and modernity (Angelo, 2010; Haber, 1999).

While this can be perceived as part of the continuities observed during this final phase, it needs to be emphasized that these land use strategies are not comparable to those observed in previous periods. The depletion of the desert forests for their use as wood and fuel produced a major transformation in the local ecology. More importantly, management of water has become increasingly problematic but the scarcity of this resource has not prevent the thriving of the extractive economy. Today, the technological systems introduced in the Atacama have been taken to the extreme to supply an enormous demand of water for irrigation, mining, and urban consumption. Despite the long-term human and environmental interaction in the Atacama Desert, the colonial discourse, which persists today, is that the desert is a wild and culturally empty space that has to be tamed and domesticated. This situation intensified after the Pacific War conflict (18791883), when Chile incorporated the territories of Atacama and Tarapacá and both state and foreign companies strengthened the narrative of the desert as an empty and marginal land to enforce industrial technology and modernization.

\section{Discussion}

The scale, intensity and continuity of human adaptive strategies in relation to changes in ecosystem services (i.e., hydrological cycles and biological communities) have been diverse and variable throughout the last $13 \mathrm{ka}$. Major humid periods followed by dry phases impacted three socio-environmental systems. The first developed between 14 and 10 ka when ground and surface water permanently flowed in abundance from the high Andes to the Pacific coast, as a result of a large post-glacial pluvial event (Fig. 4). Social groups with low population densities established a hunting and gathering way of life in the PDT within the core of the Atacama Desert. People maintained connections to highland and coastal patches to obtain, among other products lithic and marine resources. A clear discontinuity in the paleoenvironmental record of the southernmost PDT basin between 10 and $3 \mathrm{ka}$ (with occasional fluctuations) characterized by increased aridity that brought about the lowest water availability of the last $13 \mathrm{ka}$ with an absence of intermittent or even perennial surface discharge and extremely reduced bioproductivity. People were not able to maintain a hunter-gatherer social system that involved permanently living in the desert and therefore, migrated to the north into the coastal exoreic valleys and to the east towards the "sierra" and Altiplano highlands.

Around $3 \mathrm{ka}$ a new, although less abundant cycle of increased rainfall in the highlands reactivated ground and surface water in the hyperarid core of the Atacama. The increasingly available ecosystem services enhanced by the development of complex technologies of water management, and new social and ideological structures featured the resettlement of the PDT. The communities who reoccupied the region transformed the landscape by building complex and ceremonial architecture, managing all sorts of wild and cultivated resources, and constructing extensive agricultural fields around the villages. These changes constitute quantitative and qualitative innovations triggered by internal socio-cultural factors favored by adequate environmental conditions, which were capitalized by the communities in the PDT. The possible introduction into the PDT of several Prosopis species, which edible pods were part of the staple food and its wood forms raw material for different purposes. All these innovations allowed people to establish a new socio-cultural circle of life centered in the PDT during the late Holocene. 
The wetter period ended around $1.1 \mathrm{ka}$, causing communities to move to higher oases and sierra where they engaged with different ecosystem services by developing novel systems of land use and management. As water availability fluctuated throughout the subsequent centuries, human communities responded by decreasing the intensity of their permanent presence in the PDT, often moving upstream into the quebradas that (only occasionally) drained into the basin. Certainly, these environmental fluctuations cannot explain the full range of complex sociopolitical variability observed throughout the late prehistoric period in the Atacama Desert, but they were a significant constraint affecting how and which decisions were made by people regarding the use of this landscape and its resources.

The Spanish Conquest completely transformed the social and environmental interactions in the entire South American continent and not just the Atacama Desert. The new socio-ecological paradigm involved an extractive mentality that saw the Desert as an "empty" and "wild" territory that needed to be "tamed". Today, the technological systems introduced in the Atacama during the Formative and slightly modified over the following centuries have been taken to the extreme the exploitation of natural resources, and supply an enormous demand for fresh water used for mining, urban development, and agriculture.

As guano, saltpeter and latter copper became attractive global commodities, during the second half of the 19th century, groundwater pumping became necessary to cope with unprecedented increased demand for freshwater for the workforce and extraction operations. Today, the technological systems introduced in the Atacama have escalated well beyond the recharging capacity of the aquifers. These likely formed during the periods of increased moisture of the late Pleistocene and thus constitute nonrenewable resources. Continuing to squeeze water out of the world's driest desert is likely to become unsustainable in the future and reflecting on the long-term trajectory of socio-natural change will become pivotal for establishing current and future management policies.

As a result of the mining intensification through commodity cycles that included guano, saltpeter, and copper, among others, and the ensuing demographic reconfigurations carried out as part of a national policy of modernization, the desert landscape experienced dramatic changes that add up to its socio-environmental history (Bermúdez, 1963; Mujica et al., 2015; Zolezzi, 1993). Thus, even as human occupation of the desert and use of its resources gradually increased since the late Pleistocene, the scale of human influence during its recent history has been unparalleled. Contrary to earlier periods, when environmental changes seem to have been more prevalent in influencing the human-nature interaction of this territory, the effects of the anthropocene during the past two centuries are immense yet remain poorly investigated.

\section{Final reflections}

Finally, given the complex history of human-environment interactions in the Atacama Desert, but more importantly, the recent history of its overexploitation, we believe that in order to avoid a disastrous socio-environmental discontinuity, presently, human societies must acknowledge that water is a non-renewable resource. Aggressive extraction of fossil freshwater by using the same technological systems that have been applied for over three thousand years is unsustainable and potentially dangerous. In this context, the critical use of water will require new technological solutions to survive, avoid systemic failures, and leave a legacy for future generations. Therefore, we call attention for the need to develop new cultural solutions and institutional paradigms to improve our current management of this landscape as well as to suppress unsustainable practices such as the aggressive pumping of the limited water stored in the PDT aquifers.

\section{Acknowledgements}

We thank Chile's CONICYT's Programa de Investigación Asociativa (PIA), Anillo project SOC1405 "Long Term Social Change and Climatic Variability in the Atacama Desert". Basic research behind this study was obtained through FONDECYT Projects 1130279, 11150089, 11150210, 1150763, 1151046, 3140008, 3150638, 3160443, FONDAP 1511009, PII20150081, and UTA Mayor $3714 / 14$

\section{References}

Adán, L., Urbina, S., 2010. Arquitectura quebradeña del Complejo Pica-Tarapacá: modos de hacer, opciones de diseño, rasgos significativos y decisiones funcionales. Actas del XVII Congreso Nacional de Arqueología Chilena. Ediciones Kultrún, Sociedad Chilena de Arqueología, Universidad Austral de Chile, Valdivia, pp. 865-876.

Adán, L., Urbina, S., Pellegrino, C., Agüero, C., 2013. Aldeas en los bosques de prosopis. Arquitectura residencial y congregacional en el período Formativo tarapaqueño (900 AC-900 DC). Estudios Atacameños Arqueología y Antropología Surandinas 45, 75-94.

Aimers, J.J., 2007. What Maya collapse? Terminal classic variation in the Maya lowlands. J. Archaeol. Res. 15, 329-377.

Albarracin-Jordan, J., Capriles, J.M., 2011. The Paleoamerican occupation of Cueva Bautista: late-Pleistocene human evidence from the Bolivian highlands. Curr. Res. Pleistocene 28, 95-98.

Aldenderfer, M.S., 1988. Middle archaic period domestic architecture from southern Peru. Science 241, 1828-1830.

Aldenderfer, M.S., 1998. Montane Foragers. Asana and the South Central Andean Archaic. University of Iowa Press, Iowa.

Aldenderfer, M.S., Flores Blanco, L., 2011. Reflexiones para avanzar en los estudios del período Arcaico en los Andes Centro-Sur. Chungara Revista de Antropología Chilena 43, 531-550.

Anderson, N.J., Bugmann, H., Dearing, J.A., Gaillard, M.J., 2006. Linking palaeoenvironmental data and models to understand the past and to predict the future. Trends Ecol. Evol. 21, 696-704.

Andrade, P., Castro, V., Aldunate, C., 2016. Reconstrucción del modo de vida de individuos del arcaico de la costa arreica del norte de Chile: una aproximación bioarqueológica desde el sitio Copaca 1. Chungara Revista de Antropología Chilena 48, 73-90.

Angelo, D., 2010. The Compulsive Construction of Heritage: Material Culture and Identity at the Dawn of the 21st Century in Northwestern Argentina Ph.D Dissertation. Department of Anthropology, Stanford University, Stanford.

Arriaza, B.T., 1995a. Beyond Death. The Chinchorro Mummies of Ancient Chile. Smithsonian Institution Press, Washington D.C.

Arriaza, B.T., 1995b. Chinchorro bioarchaeology: chronology and mummy seriation. Lat. Am. Antiq. 6, 35-55.

Arriaza, B.T., Doubrava, M., Standen, Vivien, G., Haas, H., 2005. Differential mortuary treatment among the Andean Chinchorro fishers: social inequalities or In situ regional cultural evolution? Curr. Anthropol. 46, 662-671.

Assessment, M.E., 2005. Ecosystems and Well-Being. Island Press, Washington, D.C.

Baker, P.A., Fritz, S.C., 2015. Nature and causes of Quaternary climate variation of tropical South America. Quatern. Sci. Rev. 124, 31-47.

Baker, P.A., Seltzer, G.O., Fritz, S.C., Dunbar, R.B., Grove, M.J., Tapia, P.M., Cross, S.L., Rowe, H.D., Broda, J.P., 2001. The history of South American tropical precipitation for the past 25,000 years. Science 291, 640-643.

Beresford-Jones, D.G., Lewis, H., Boreham, S., 2009. Linking cultural and environmental change in Peruvian prehistory: geomorphological survey of the Samaca Basin, Lower Ica Valley, Peru. Catena 78, 234-249.

Bermúdez, O., 1963. Historia Del Salitre Desde Sus Orígenes Hasta La Guerra Del Pacífico. Ediciones de la Universidad de Chile, Santiago.

Betancourt, J.L., Latorre, C., Rech, J.A., Quade, J., Rylander, K.A., 2000. A 22,000-year record of monsoonal precipitation from Northern Chile's Atacama Desert. Science 289, 1542-1546.

Binford, M.W., Kolata, A.L., Brenner, M., Janusek, J.W., Seddon, M.T., Abbott, M., Curtis, J.H., 1997. Climate variation and the rise and fall of an Andean civilization. Quatern. Res. 47, 235-248.

Bird, J., 1943. Excavations in Northern Chile. American Museum of Natural History New York.

Boyd, R., Richerson, P.J., 2005. The Origin and Evolution of Cultures. Oxford University Press, Oxford.

Boyd, R., Richerson, P.J., Henrich, J., 2011. The cultural niche: why social learning is essential for human adaptation. Proc. Natl. Acad. Sci. 108, 10918-10925.

Briner, C., 1985. Caracterización fenotípica de los biotipos de Tamarugo en la Pampa del Tamarugal. In: Habit, M.A. (Ed.), Estado Actual Del Conocimiento Sobre Prosopis Tamarugo. Documentos Presentados a La Mesa Redonda Internacional Sobre Prosopis Tamarugo Phil. FAO, Arica, Chile, p. 500. 
Briones, L., Núñez, L., Standen, V.G., 2005. Geoglifos y tráfico prehispánico de caravanas de llamas en el desierto de Atacama (norte de Chile). Chungara, Revista de Antropología Chilena 37, 195-223.

Cabello, G., Gallardo, F., 2014. Iconos claves del Formativo en Tarapacá (Chile): El arte rupestre de Tamentica y su distribución regional. Chungara Revista de Antropología Chilena 46, 11-24.

Capriles, J.M., Albarracin-Jordan, J., 2013. The earliest human occupations in Bolivia: a review of the archaeological evidence. Quatern. Int. 301, 46-59.

Capriles, J.M., Albarracin-Jordan, J., Lombardo, U., Osorio, Daniela., Herrera, K.A., Maley, B., Goldstein, S.T., Domic, A.I., Glascock, M.D., Veit, H., Santoro, C.M., 2016. High-altitude adaptation and late Pleistocene foraging in the Bolivian Andes. J. Archaeol. Sci. Rep. 6, 463-474.

Capriles, J.M., Calla, S., Albarracín-Jordán, J., 2011. Tecnología lítica y estrategias de subsistencia durante los periodos Arcaico y Formativo en el altiplano central Bolivia. Chungara Revista de Antropología Chilena 43, 455-468.

Cartajena, I., 2013. Faunal assemblages from the Middle Holocene: environmental and cultural variability in the western slope of the Puna de Atacama. Quatern. Int. 307, 31-37.

Castro, V., Escobar, M., Salazar, D., 2012. Una mirada antropológica al devenir minero de Taltal y Paposo. Chungara Revista de Antropología Chilena 44, 401417.

Christie, J., 2009. Piedras talladas Inka y yupanas: una posible esencia compartida. Arqueología del Area Centro Sur Andina. Actas del Simposio Internacional, Arequipa, Perú 7, 525-545.

Clarke, D.L., 1968. Analytical Archaeology. Methuen, London.

Costanza, R., Graumlich, L., Steffen, W., Crumley, C., Dearing, J., Hibbard, K. Leemans, R., Redman, C., Schimel, D., 2007. Sustainability or collapse: what can we learn from integrating the history of humans and the rest of nature? Ambio $36,522-527$

Crutzen, P.J., 2002. Geology of mankind. Nature 415, 23-23.

de Porras, M.E., Maldonado, A., Zamora-Allendes, A., Latorre, C., 2015. Calibrating the pollen signal in modern rodent middens from northern Chile to improve the interpretation of the late Quaternary midden record. Quatern. Res. 84, 301-311.

de Souza, P., 2004. Cazadores y recolectores del Arcaico Temprano y Medio en la cuenca superior del río Loa: sitios, conjuntos líticos y sistemas de asentamiento. Estud. Atacameños 27, 7-43.

Dearing, J.A., Acma, B., Bub, S., Chambers, F.M., Chen, X., Cooper, J., Crook, D., Dong, X.H., Dotterweich, M., Edwards, M.E., Foster, T.H., Gaillard, M.-J., Galop, D., Gell, P., Gil, A., Jeffers, E., Jones, R.T., Anupama, K., Langdon, P.G., Marchant, R., Mazier, F., McLean, C.E., Nunes, L.H., Sukumar, R., Suryaprakash, I., Umer, M., Yang, X.D., Wang, R., Zhang, K., 2015. Social-ecological systems in the Anthropocene: the need for integrating social and biophysical records at regional scales. Anthropocene Rev. 2, 220-246.

Dearing, J.A., Battarbee, R.W., Dikau, R., Larocque, I., Oldfield, F., 2006. Humanenvironment interactions: learning from the past. Reg. Environ. Change 6, 1-16.

deFrance, S.D., Umire, A., 2004. Quebrada Tacahuay: un sitio marítimo del pleistoceno tardío en la costa sur del Perú. Chungara, Revista de Antropología Chilena 36, 257-278.

Ellis, E.C., 2015. Ecology in an anthropogenic biosphere. Ecol. Monogr. 85, 287-331.

Fritz, S.C., Baker, P.A., Tapia, P., Spanbauer, T., Westover, K., 2012. Evolution of the Lake Titicaca basin and its diatom flora over the last $\sim 370,000$ years. Palaeogeogr. Palaeoclimatol. Palaeoecol. 317-318, 93-103.

Gajardo, R., 1994. La Vegetación Natural De Chile. Editorial Universitaria, Santiago.

García, M., Vidal, A., Mandakovic, V., Maldonado, A., Peña, M.P., Belmonte, E., 2014 Alimentos, tecnologías vegetales y paleoambiente en las aldeas de la Pampa de Tamarugal: dos expresiones del periodo Formativo en Tarapacá (ca. 900 a.C.800 d.C.). Estudios Atacameños Arqueología y Antropología Surandina 47, $33-$ 58.

Gayo, E.M., Latorre, C., Jordan, T.E., Nester, P.L., Estay, S.A., Ojeda, K.F., Santoro, C.M., 2012a. Late Quaternary hydrological and ecological change in the hyperarid core of the northern Atacama Desert ( $21^{\circ}$ S). Earth-Sci. Rev. 113, 120-140.

Gayo, E.M., Latorre, C., Santoro, C.M., 2015. Timing of occupation and regiona settlement patterns revealed by time-series analyses of an archaeological radiocarbon database for the South-Central Andes $\left(16^{\circ}-25^{\circ} \mathrm{S}\right)$. Quatern. Int. 356, 4-14.

Gayo, E.M., Latorre, C., Santoro, C.M., Maldonado, A., De Pol-Holz, R., 2012b. Hydroclimate variability on centennial timescales in the low-elevation Atacama Desert over the last 2500 years. Clim. Past 8, 287-306.

Gayo, E.M., Santoro, C.M., Latorre, C., 2014. Past human demography as environmental Proxy: exploring Its potential with an example from the arid western Andean region. In: 4th Southern Desert Conference, Mendoza, Argentina.

Geleta, B., 2014. Building Resilience for Vulnerable People and Communities Through Improved Food and Nutrition Security. International Federation of Red Cross and Red Crescent Societies.

Giralt, S., Moreno, A., Bao, R., Sáez, A., Prego, R., Valero-Garcés, B., Pueyo, J., González-Sampériz, P., Taberner, C., 2008. A statistical approach to disentangle environmental forcings in a lacustrine record: the Lago Chungará case (Chilean Altiplano). J. Paleolimnol. 40, 195-215.

Gluzman, G., 2007. Minería y metalurgia en la antigua gobernación del Tucumán (siglos XVI-XVII). Memoria Americana. Cuadernos de Etnohistoria 15, 157-184.

González-Silvestre, L., Maldonado, A., Núñez, L., Cartajena, I., Carrasco, C., de Souza, P., 2013. Condiciones paleovegetacionales y asentamientos humanos durante el Formativo temprano: análisis de polen del sitio Tulán-85 (1.530/1.260-460/420 años cal. a.c.), cuenca del Salar de Atacama. Chungara Revista de Antropología Chilena 45, 387-410.
Grosjean, M., Cartajena, I., Geyh, M.A., Nunez, L., 2003. From proxy data to paleoclimate interpretation: the mid-Holocene paradox of the Atacama Desert, northern Chile. Palaeogeogr. Palaeoclimatol. Palaeoecol. 194, 247-258.

Grosjean, M., Messerli, B., Ammann, C., Geyh, M.A., Graf, K., Jenny, B., Kammer, K., Núñez, L., Schreier, H., Schotterer, U., Schwalb, A., Valero-Garcés, B., Vuille, M., 1995. Holocene environmental changes in the Atacama Altiplano and paleoclimatic implications. Bulletin de l'Institut Français d'Études Andines 24, 585-594.

Grosjean, M., Núñez, L., Cartajena, I., 2005. Cultural response to climate change in the Atacama Desert. In: Smith, M., Hesse, P. (Eds.), $23^{\circ}$ South: Archaeology and Environmental History of the Southern Deserts. National Museum of Australia Press, Canberra, pp. 156-171.

Grosjean, M., Nuñez, L., Cartajena, I., Messerli, B., 1997. Mid-Holocene climate and culture change in the Atacama Desert, northern Chile. Quatern. Res. 48, 239246.

Grosjean, M., Santoro, C.M., Thompson, L., Núñez, L., Standen, V.G., 2007. MidHolocene climate and culture change in the south-central Andes. In: Anderson, D.G., Maasch, K.A., Sandweiss, D.H. (Eds.), Climate Change and Cultural Dynamics: A Global Perspective on Mid-Holocene Transitions. Elsevier, San Diego, pp. 51-115.

Grosjean, M., van Leeuwen, J.F.N., van der Knaap, W.O., Geyh, M.A., Ammann, B., Tanner, W., Messerli, B., Núñez, L., Valero-Garces, B.L., Veit, H., 2001. A 22,000 C14 year BP sediment and pollen record of climate change from Laguna Miscanti (23 degrees S), northern Chile. Global Planet. Change 28, 35-51.

Haber, A., 1999. Caspichango, la ruptura metafísica y la cuestión colonial en la arqueología sudamericana: el caso del noroeste argentino. Revista do Museu de Arqueologia e Etnologia 3, 129-141.

Henrich, J., 2004. Demography and cultural evolution: how adaptive cultural processes can produce maladaptive losses: the Tasmanian case. Am. Antiq. 69, 197-214.

Henrich, J., 2008. A cultural species. In: Brown, M. (Ed.), Explaining Culture Scientifically. University of Washington Press, Seattle, pp. 184-210.

Herrera, K., Ugalde, P.C., Osorio, D., Capriles, J.M., Hocsman, S., Santoro, C.M., 2015. Análisis tecno-tipológico de instrumentos líticos del sitio Arcaico Temprano Ipilla 2 en los Andes de Arica, Chile. Chungara Revista de Antropología Chilena 47, 41-52.

Holmgren, C.A., Rosello, E., Latorre, C., Betancourte, J.L., 2008. Late-Holocene fossil rodent middens from the Arica region of northernmost Chile. J. Arid Environ. 72, 677-686.

Holmgren, M., Stapp, P., Dickman, C.R., Gracia, C., Graham, S., Gutiérrez, J.R., Hice, C., Jaksic, F.M., Kelt, D.A., Letnic, M., 2006. Extreme climatic events shape arid and semiarid ecosystems. Front. Ecol. Environ. 4, 87-95.

Houston, J., 2006. Variability of precipitation in the Atacama Desert: its causes and hydrological impact. Int. J. Climatol. 26, 2181-2198.

IPCC-AR4, 2007. Contribution of Working Groups I, II and III to the Fourth Assessment Report of the Intergovernmental Panel on Climate Change Core Writing Team Pachauri, R.K., Reisinger, A. IPCC, Geneva.

Jackson, D., Maldonado, A., Carré, M., Seguel, R., 2011. Huentelauquén cultural complex: the earliest peopling of the Pacific coast in the SouthAmerican southern cone. In: Vialou, D. (Ed.), Peuplement et Préhistoire en Amériques. Éditions du Comité des Travaux Historiques et Scientifiques, Paris, pp. 221-231.

Jaksic, F.M., 2001. Ecological effects of El Niño terrestrial ecosystems of western South America. Ecography 24, 241-250.

Jimenez, M.A., Jaksic, F.M., Armesto, J.J., Meserve, P.L., Kelt, D.A., Gutierrez, J.R., 2011. Extreme climatic events change the dynamics and invasibility of semi-arid annual plant communities. Ecol. Lett. 14, 1227-1235.

Keefer, D.K., deFrance, S.D., Moseley, M., Richardson III, J.B., Satterlee, D.R., DayLewis, A., 1998. Early maritime economy and El Niño events at Quebrada Tacahuay, Peru. Science 281, 1833-1835.

Kintigh, K.W., Altschul, J.H., Beaudry, M.C., Drennan, R.D., Kinzig, A.P., Kohler, T.A., Limp, W.F., Maschner, H.D.G., Michener, W.K., Pauketat, T.R., Peregrine, P., Sabloff, J.A., Wilkinson, T.J., Wright, H.T., Zeder, M.A., 2014a. Grand challenges for archaeology. Proc. Natl. Acad. Sci. 111, 879-880.

Kintigh, K.W., Altschul, J.H., Beaudry, M.C., Drennan, R.D., Kinzig, A.P., Kohler, T.A., Limp, W.F., Maschner, H.D.G., Michener, W.K., Pauketat, T.R., Peregrine, P., Sabloff, J.A., Wilkinson, T.J., Wright, H.T., Zeder, M.A., 2014b. Grand challenges for archaeology. Am. Antiq. 79, 5-24.

Klink, C., Aldenderfer, M.S., 2005. A proyectile point chronology for the South Central Andean highlands. In: Stanish, C., Cohen, A.E., Aldenderfer, M.S. (Eds.), Advance in Titicaca Basin Archaeology. Costen Institute of Archaeology, Los Angeles, California, pp. 25-54.

Kohler, T.A., Bocinsky, R.K., Cockburn, D., Crabtree, S.A., Varien, M.D., Kolm, K.E., Smith, S., Ortman, S.G., Kobti, Z., 2012. Modelling prehispanic Pueblo societies in their ecosystems. Ecol. Model. 241, 30-41.

Kuentz, A., 2012. Vegetation changes during the past 1000 years in the southern Andes (Coropuna, Peru). Quatern. Int. 279-280, 258.

Latorre, C., Betancourt, J.L., Arroyo, M.T.K., 2006. Late Quaternary vegetation and climate history of a perennial river canyon in the Río Salado basin $\left(22^{\circ} \mathrm{S}\right)$ of northern Chile. Quatern. Res. 65, 405-466.

Latorre, C., Betancourt, J.L., Rylander, K.A., Quade, J., 2002. Vegetation invasions into absolute desert: a 45,000-yr rodent midden record from the Calama-Salar de Atacama basins, northern Chile (22-24 S). Geol. Soc. Am. Bull. 114, 349-366.

Latorre, C., Betancourt, J.L., Rylander, K.A., Quade, J., Matthei, O., 2003. A vegetation history from the arid prepuna of northern Chile $\left(22-23^{\circ} \mathrm{S}\right)$ over the last 13,500 years. Palaeogeogr. Palaeoclimatol. Palaeoecol. 194, 223-246. 
Latorre, C., Santoro, C.M., Ugalde, P.C., Gayó, E.M., Osorio, D., Salas-Egaña, C., De PolHolz, R., Joly, D., Rech, J.A., 2013. Late Pleistocene human occupation of the hyperarid core in the Atacama Desert, northern Chile. Quatern. Sci. Rev. 77, 1930.

Le Houerou, H.N., 1992. Outline of the biological history of the Sahara. J. Arid Environ. 22, 3-30.

Ledru, M.-P., Jomelli, V., Samaniego, P., Vuille, M., Hidalgo, S., Herrera, M., Ceron, C., 2013. The Medieval climate anomaly and the Little Ice Age in the eastern Ecuadorian Andes. Clim. Past 9, 307-321.

Llagostera, A., 2003. Patrones de momificación Chinchorro en las colecciones Uhle y Nielsen. Chungara Revista de Antropología Chilena 35, 5-22.

Llagostera, A., Kong, I., Iratchet, P., 1997. Análisis ictioarqueológico del sitio La Chimba 13 (II Región, Chile). Chungara 29, 163-180.

Luebert, F., Pliscoff, P., 2006. Sinopsis Bioclimática Y Vegetacional De Chile. Editorial Universitaria, Santiago.

Magaritz, M., Aravena, R., Peña, H., Suzuki, O., Grilli, A., 1990. Source of ground water in the deserts of northern Chile: evidence of deep circulation of ground water from the Andes. Ground Water 28, 513-517.

Maldonado, A., Betancourt, J.L., Latorre, C., Villagrán, C., 2005. Pollen analyses from a 50,000-yr rodent midden series in the southern Atacama Desert (25³0'S). J. Quat. Sci. 20, 493-507, DOI: 410.1002/jqs.1936.

Maldonado, A., Uribe, M., 2015. Paleoambientes y ocupaciones humanas en Tarapacá durante el período Formativo y comienzos del Intermedio Tardío. Actas del XIX Congreso Nacional de Arqueología Chilena. Universidad de Tarapacá, Sociedad Chilena de Arqueología, Arica, pp. 193-200.

Marquet, P.A., Santoro, C.M., Latorre, C., Standen, V.G., Abades, S.R., Rivadeneira, M. M., Arriaza, B.T., Hochberg, M.E., 2012. Emergence of social complexity among coastal hunter-gatherers in the Atacama Desert of northern Chile. PNAS 109, $14754-14760$.

McRostie, V.B., 2013. The Role of Plant Production in Subsistence and Cultural Changes During the Formative Period in the Atacama Puna, Southern Andes, Chile (1400 B.C.- A.D. 500). A Re-evaluation Based on the Analyses of Microfossils Attached to Hoes and Grinding Tools, and Isotopic Analyses of Human Bones Ph.D Thesis. University College London.

McRostie, V.B., 2014. Arboricultura y silvopastoralismo en el período Formativo (1.400 a.c.-500 d.C.) de la cuenca del Salar de Atacama. Chungara, Revista de Antropología Chilena 46, 543-557.

Mendez-Quiroz, P., Uribe, M., 2010. Análisis estratigráfico y cronología del Complejo Cultural Pica-Tarapacá (CA. 900-1450 años DC). Actas del XVII Congreso Nacional de Arqueología Chilena, editado. Ediciones Kultrún, Sociedad Chilena de Arqueología, Universidad Austral de Chile, Valdivia, pp. 47-58.

Minvielle, M., Garreaud, R.D., 2011. Projecting rainfall changes over the South American Altiplano. J. Clim. 24, 4577-4583.

Morales, M.S., Christie, D.A., Villalba, R., Argollo, J., Pacajes, J., Silva, J.S., Alvarez, C.A., Llancabure, J.C., Soliz-Gamboa, C.C., 2012. Precipitation changes in the South American Altiplano since $1300 \mathrm{AD}$ reconstructed by tree-rings. Clim. Past 8, 653-666.

Moreno, A., Santoro, C.M., Latorre, C., 2009. Climate change and human occupation in the northernmost Chilean Altiplano over the last ca. 11500 cal. BP. J. Quat. Sci. $24,373-382$.

Mujica, M.I., Latorre, C., Maldonado, A., González-Silvestre, L., Pinto, R., De Pol-Holz, R., Santoro, C.M., 2015. Late Quaternary climate change, relict populations and present-day refugia in the northern Atacama Desert: a case study from Quebrada La Higuera (185). J. Biogeogr. 42, 76-88.

Muñoz, A.E., Bonacic, C., 2006. Variacion estacional de la flora y vegetacion en la precordillera andina de la comuna de Putre (I region de Tarapacá, Chile) durante el periodo 2002-2003. Gayana Botánica 63, 75-92.

Muñoz, C., Guerra, N., Martinez-Frias, J., Lunar, R., Cerda, J., 2007. The Atacama Desert: a preferential arid region for the recovery of meteorites. Find location features and strewnfield distribution patterns. J. Arid Environ. 71, 188-200.

Nester, P.L., Gayo, E., Latorre, C., Jordan, T.E., Blanco, N., 2007. Perennial stream discharge in the hyperarid Atacama Desert of northern Chile during the latest Pleistocene. Proc. Natl. Acad. Sci. USA 104, 19724-19729.

Noy-Meir, I., 1973. Desert ecosystems: environment and producers. Annu. Rev. Ecol. Syst. 4, 51-58.

Núñez, L., 1986. Evidencias arcaicas de maíces y cuyes en Tiliviche: hacia el sedentarismo en el litoral fértil y quebradas del Norte de Chile. Chungara 16-17, 25-49.

Núñez, L., Cartajena, I., Grosjean, M., 2013. Archaeological silence and ecorefuges: arid events in the Puna of Atacama during the Middle Holocene. Quatern. Int. 307, 5-13.

Núñez, L., Grosjean, M., 1994. Cambios ambientales pleistocenico-holocenicos: ocupacion humana y uso de recursos en Ia Puna de Atacama (norte de Chile). Estudios Atacameños 11, 11-24.

Núñez, L., Grosjean, M., 2003. Biodiversity and human impact during the last 11,000 years in North-Central Chile. In: Bradshaw, G.A., Marquet, P.A. (Eds.), How Landscapes Change, Ecological Studies, vol. 162. Springer Verlag, Berlin, Heidelberg, pp. 7-17.

Núñez, L., Grosjean, M., Cartajena, I., 2002. Human occupations and climate change in the Puna de Atacama, Chile. Science 298, 821-824.

Núñez, L., Grosjean, M., Cartajena, I., 2010. Sequential analysis of human occupation patterns and resource use in the Atacama Desert. Chungara Revista de Antropología Chilena 42, 363-391.

Núñez, L., Grosjean, M., Cartajena, I., Pino, M., 1995. Proyectos Puripica: reconstrucción multidisciplinaria de eventos holocénicos cultural y ambientales. Actas del XIII Congreso Nacional de Arqueología Chilena. Universidad de Antofagasta, Antofagasta, pp. 273-289.

Núñez, L., Jackson, D., Dillehay, T.D., Santoro, C.M., Méndez, C., 2016. Cazadoresrecolectores tempranos y los primeros poblamientos en Chile hacia finales de Pleistoceno (ca.13.000-10.000 años antes del presente). In: Aldunate, C., Falabella, F., Sanhueza, L., Hidalgo, J., Uribe, M. (Eds.), Prehistoria en Chile desde sus Primeros Habitantes hasta los Incas. Editorial Universitaria, Santiago.

Núñez, L., Santoro, C.M., 1990. Primeros poblamientos en el cono sur de América (XII-IX milenio A.P.). Revista de Arqueología Americana 1, 91-139.

Núñez, L., Santoro, C.M., 2011. El tránsito Arcaico-Formativo en la circunpuna y valles occidentales del Centro Sur Andino: hacia los cambios "neolíticos" Chungara Revista de Antropología Chilena 43, 487-531.

Núñez, P., Zlatar, V., 1976. Radiometría De Aragón-1 Y Sus Implicancias En El Precerámico Costero Del Norte De Chile. Actas y Memorias del IX Congreso Nacional de Arqueología Argentina, San Juan, pp. 67-103.

Olguín, L., Salazar, D., Jackson, D., 2014. Tempranas evidencias de navegación y caza de especies oceánicas en la costa pacífica de Sudamérica (Taltal, $\sim 7.000$ años cal. a.p.). Chungara Revista de Antropología Chilena 46, 177-192.

Ortega, C., Vargas, G., Rutllant, J., Jackson, D., Méndez, C., 2012. Early Holocene major hydrological regime change along the semiarid western coast of South America. Quatern. Res. 78, 513-527.

Osorio, D., Jackson, D., Ugalde, P.C., Latorre, C., De Pol-Holz, R., Santoro, C.M., 2011. Hakenasa Cave and its relevance for the peopling of the southern Andean Altiplano. Antiquity 85, 1194-1208.

Palmer, P.I., Smith, M.J., 2014. Model human adaptation to climate change. Nature 512, 365-366.

Pestle, W.J., Torres-Rouff, C., Hubbe, M., Santana, F., Pimentel, G., Gallardo, F. Knudson, K.J., 2015. Explorando la diversidad dietética en la prehistoria del Desierto de Atacama: un acercamiento a los patrones regionales. Chungara Revista de Antropología Chilena 47, 201-209.

Pintar, E., 2014. Continuidades e hiatos ocupacionales durante el Holoceno medio en el borde oriental de la Puna Salada, Antofagasta de la sierra, Argentina. Chungara, Revista de Antropología Chilena 46, 51-71.

Placzek, C., Quade, J., Betancourt, J.L., 2001. Holocene lake-level fluctuations of Lake Aricota, southern Peru. Quatern. Res. 56, 181-190.

Placzek, C., Quade, J., Betancourt, J.L., Patchett, P.J., Rech, J.A., Latorre, C., Matmon, A., Holmgren, C., English, N.B., 2009. Climate in the dry central Andes over geologic, millennial, and Interannual timescales. Ann. Mo. Bot. Gard. 96, 386-397.

Placzek, C., Quade, J., Patchett, P.J., 2006. Geochronology and stratigraphy of Late Pleistocene lake cycles on the Southern Bolivian Altiplano: implications for causes of tropical climate change. Geol. Soc. Am. Bull. 118, 515-532.

Powell, A., Shennan, S., Thomas, M.G., 2009. Late Pleistocene demography and the appearance of modern human behavior. Science 324, 1298-1301.

Quade, J., Rech, J.A., Betancourt, J.L., Latorre, C., Quade, B., Rylander, K.A., Fisher, T. 2008. Paleowetlands and regional climate change in the central Atacama Desert, northern Chile. Quatern. Res. 69, 343-360.

Rech, J.A., 2001. Late Quaternary Paleohydrology and Surficial Processes of the Atacama Desert, Chile: Evidence from Wetland Deposits and Stable Isotopes of Soil Salts Ph.D. Dissertation. Department of Geosciences. The University of Arizona, Tucson, p. 222.

Rech, J.A., Pigati, J.S., Quade, J., Betancourt, J.L., 2003. Re-evaluation of mid-Holocene deposits at Quebrada Puripica, northern Chile. Palaeogeogr. Palaeoclimatol. Palaeoecol. 194, 207-222.

Rech, J.A., Quade, J., Betancourt, J.L., 2001. Paleoclimatic reconstruction of the Atacama Desert $\left(18-26^{\circ} \mathrm{S}\right)$ : evidence from wetland deposits. In: Proceedings from the Central Andean Paleoclimate Workshop, January 11-16th, Tucson, Arizona. Available online at <http://wwwpaztcn.wr.usgs.gov/pcaw/abstracts/ Rech_ea.pdf>.

Rech, J.A., Quade, J., Betancourt, J.L., 2002. Late Quaternary paleohydrology of the Central Atacama Desert $\left(22-24^{\circ}\right)$, Chile. Geol. Soc. Am. Bull. 114, 334 348.

Rivera, M.A., 1995. The preceramic Chinchorro mummy complex of northern Chile: context, style, and purpose. In: Dillehay, T.D. (Ed.), Tombs for the Living: Andean Mortuary Practices. Dumbarton Oaks Research Library and Collection, Washington, D.C., pp. 43-77.

Rivera, M.A., 2005. Arqueología Del Desierto De Atacama. La Etapa Formativa En El Área De Ramaditas/Guatacondo, Colección Estudios Regionales Y Locales. Universidad Bolivariana, Santiago.

Roscoe, P., 2014. A changing climate for anthropological and archaeological research? Improving the climate-change models. Am. Anthropol. 116, 1-14.

Rowland, M.J., 2008. Landscape and climate change. In: David, B., Thomas, J. (Eds.), Handbook of Landscape Archaeology. Left Coast Press, Walnut Creek, pp. 386395.

Rozas, C., 2014. Arquitectura y paisaje temprano en quebradas tarapaqueñas. ocupaón humana prehispácica en quebrada Maní durante el periodo Formativo: un acercamienbti desde la arqueología relacional. Universidad Sek, Facultas de Estudios de Patrimonio Cultural, Carrera de Arquoelogía. Universidad Sek, Santiago.

Salazar, D., Figueroa, V., Andrade, P., Salinas, H., Olguín, L., Power, X., Rebolledo, S. Parra, S., Orellana, H., Urrea, J., 2015. Cronología y organización económica de las poblaciones arcaicas de la costa de Taltal. Estudios Atacameños Arqueología y Antropología Surandinas 50, 7-46.

Salazar, D., Jackson, D., Guendon, G.L., Salinas, H., Morata, D., Figueroa, V., Manríquez, G., Castro, V., 2011. Early evidence (ca. 12,000 BP) for iron oxide mining on the Pacific coast of South America. Curr. Anthopol. 52, 463-475. 
Sandweiss, D.H., McInnis, H., Burger, R.L., Cano, A., Ojeda, B., Paredes, R., Sandweiss, M.d.C., Glascock, M.D., 1998. Quebrada Jaguay: early South American maritime adaptations. Science 281, 1830-1832.

Santoro, C.M., 1989. Antiguos cazadores de la puna (9000-6000 a.C.). In: Hidalgo, J., Schiappacasse, V., Niemeyer, H., Aldunate, C., Solimano, I. (Eds.), Culturas de Chile. Prehistoria, desde sus Orígenes hasta los Albores de la Conquista. Editorial Andrés Bello, Santiago, pp. 33-55.

Santoro, C.M., Cartajena, I., Maldonado, A., Gayó, E.M., Latorre, C., Rivadeneira, M.M. Standen, V.G Arriaza, B.T, Rothhammer, F, Osorio, D. Ugalde, P.C, Valenzuela, D., Sepúlveda, M., de Souza, P., Núñez, L., 2016. Cazadores, recolectores y pescadores arcaicos del Desierto de Atacama. entre el Pacífico y los Andes, norte de Chile (ca. 10.000 - 3.700 años a.p.). In: Aldunate, C., Falabella, F., Sanhueza, L., Hidalgo, J., Uribe, M. (Eds.), Prehistoria en Chile desde sus Primeros Habitantes hasta los Incas. Editorial Universitaria, Santiago.

Santoro, C.M., Latorre, C., Salas, C., Osorio, D., Ugalde, P., Jackson, D., Gayó, E.M., 2011a. Ocupación humana pleistocénica en el Desierto de Atacama Primeros resultados de la aplicación de un modelo predictivo interdisciplinario. Chungara Revista de Antropología Chilena 43, 353-366.

Santoro, C.M., Núñez, L., 1987. Hunters of the Dry Puna and Salt Puna in northern Chile. Andean Past 1, 57-110.

Santoro, C.M., Osorio, D., Standen, V.G., Ugalde, P.C., Herrera, K., Gayó, E.M. Rothhammer, F., Latorre, C., 2011b. Ocupaciones humanas tempranas y condiciones paleoambientales en el desierto de Atacama durante la transición Pleistoceno-Holoceno. Boletín de Arqueología Pontificia Universidad Católica de Perú 15, 1-20.

Sheffield, J., Wood, E., 2008. Projected changes in drought occurrence under future global warming from multi-model, multi-scenario, IPCC AR4 simulations. Clim. Dyn. 31, 79-105.

Smith, B.D., Zeder, M.A., 2013. The onset of the Anthropocene. Anthropocene 4, 8 13.

Squeo, F.A., Warner, B.G., Aravena, R., Espinoza, D., 2006. Bofedales: high altitude peatlands of the central Andes. Revista Chilena de Historia Natural 79, 245-255.

Standen, V., Arriaza, B., 2016. Cultura Chinchorro Catálogo de Artefactos. Universidad de Tarapacá, Arica.

Standen, V.G., 1997. Temprana Complejidad Funeraria de la Cultura Chinchorro (Norte de Chile). Lat. Am. Antiq. 8, 134-156.

Standen, V.G., Santoro, C.M., Arriaza, B.T., 2004. Síntesis y propuesta para el período Arcaico en la costa del extremo norte de Chile. Chungara Revista de Antropología Chilena Volumen Especial, 201-212.

Sylvestre, F. Servant, M., Servant-Vildary, S., Causse, C., Fournier, M., Ybert, J.-P. 1999. Lake-level chronology on the Southern Bolivian Altiplano $\left(18^{\circ}-23^{\circ} \mathrm{S}\right)$ during late-glacial time and the early Holocene. Quatern. Res. 51, 54-66.

Thiel, M., Macaya, E.C., Acuna, E., Arntz, W.E., Bastias, H., Brokordt, K., Camus, P.A., Castilla, J.C. Castro, L.R., Cortes, M., Dumont, C.P., Escribano, R., Fernandez, M. Gajardo, J.A., Gaymer, C.F., Gomez, I., Gonzalez, A.E., Gonzalez, H.E., Haye, P.A. Illanes, J.E., Iriarte, J.L., Lancellotti, D.A., Luna-Jorquerai, G., Luxoroi, C., Manriquez, P.H., Marin, V., Munoz, P., Navarrete, S.A., Perez, E., Poulin, E., Sellanes, J., Sepulveda, H.H., Stotz, W., Tala, F., Thomas, A., Vargas, C.A., Vasquez, J.A., Vega, J.M.A., 2007. The Humboldt current system of northern and central Chile. Oceanogr. Mar. Biol. 45, 195-344.

Timpson, A., Colledge, S., Crema, E., Edinborough, K., Kerig, T., Manning, K., Thomas, M.G., Shennan, S., 2014. Reconstructing regional population fluctuations in the European Neolithic using radiocarbon dates: a new case-study using an improved method. J. Archaeol. Sci. 52, 549-557.

Ugalde, P.C., Salas, C., Latorre, C., Osorio, D., Jackson, D., Santoro, C.M., 2012. Poblamiento Temprano Del Norte De Chile $\left(18-25^{\circ} \mathrm{S}\right)$ : Estudio Interdisciplinario Arqueológico Y Paleoambiental. Actas XVIII Congreso Nacional de Arqueología Chilena. Sociedad Chilena de Arqueología, Santiago, pp. 197-206.

Urbina, S., Adán, L., 2006. Contrucciones de uso público y su ditribución en las quebradas tarapaqueñas durante el Período Intermedio Tardío (900-1450 DC). Boletín de la Sociedad Chilena de Arqueología 39, 19-34.
Urbina, S., Adán, L., Pellegrino, C., 2012. Arquitecturas formativas de las quebradas de Guatacondo y Tarapacá a través del proceso aldeano (ca. 900 AC-1000 DC). Boletín del Museo Chileno de Arte Precolombino 17, 31-60.

Uribe, M., 2006a. Acerca de complejidad, desigualdad social y el complejo cultural Pica-Tarapacá en los Andes centro-sur (1000-1450 DC). Estudios Atacameños 31, 91-114.

Uribe, M., 2006b. Sobre cerámica, su origen y complejidad social en los Andes del desierto de Atacama. In: Lechtman, H. (Ed.), Esferas de Interacción Prehistóricas y Fronteras Nacionales Modernas: Los Andes Sur Centrales. Instituto de Estudios Peruanos e Institute of Andean Research, Lima, pp. 449-502.

Uribe, M., 2009. El período Formativo de Tarapacá y su cerámica: avances sobre complejidad social en la costa del Norte Grande de Chile (900 AC - 800 DC). Estudios Atacameños 37, 5-27.

Uribe, M., Agüero, C., Catalán, D., Herrera, M.J., Santana-Sagredo, F., 2015. Nuevos fechados del sitio Tarapacá-40: recientes análisis y reflexiones sobre un cementerio clave del período Formativo del norte de Chile y Andes Centro Sur (1110 a.C.-660 d.C). Ñawpa Pacha 35, 57-89.

Uribe, M., Sanhueza, L., Bahamondes, F., 2007. La cerámica prehispánica tardía de Tarapacá, sus valles interiores y costa desértica, norte de Chile (ca. 900-1.450 d. C.): una propuesta tipológica y cronológica. Chungara, Revista de Antropología Chilena 39, 143-170.

Uribe, M., Vidal, E., 2012. Sobre la secuencia cerámica del período Formativo de Tarapacá (900 a.c.-900 d.c.): estudios en Pircas, Caserones, Guatacondo y Ramaditas, norte de Chile. Chungara Revista de Antropología Chilena 44, 209245.

Urrutia, R., Vuille, M. 2009. Climate change projections for the tropical Andes using a regional climate model: temperature and precipitation simulations for the end of the 21st century. J. Geophys. Res. 114, D02108.

Van der Leeuw, S., Redman, C.L., 2002. Placing archaeology at the center of socionatural studies. Am. Antiq. 67, 597-605.

Verstraeten, G., 2014. Quantification of human-environment interactions in the past. Anthropocene 8, 1-5.

Vidal, A., García, M., Méndez-Quirós, P., 2015. Producción anual versus estacional: dos estrategias de producción agrícola durante el período Formativo en Tarapacá, norte de Chile. Actas del XIX Congreso Nacional de Arqueología Chilena. Sociedad Chilena de Arqueología, Universidad de Tarapacá, Arica, pp. 183-192.

Villagrán, C., Castro, V., Sánchez, G., Hinojosa, F., Latorre, C., 1999. La tradición altiplánica: estudio etnobotánico en los Andes de Iquique, primera región, Chile. Chungara 31, 81-186.

Vuille, M., 2013. Climate Change and Water Resources in the Tropical Andes. InterAmerican Development Bank.

Wang, G., 2005. Agricultural drought in a future climate: results from 15 global climate models participating in the IPCC 4th assessment. Clim. Dyn. 25, 739753.

Washington-Allen, R.A., Ramsey, R.D., West, N.E., Norton, B.E., 2008. Quantification of the ecological resilience of drylands using digital remote sensing. Ecol. Soc. $13,33$.

Williams, A., Santoro, C.M., Smith, M.A., Latorre, C., 2008. The impact of ENSO in the Atacama Desert and Australian arid zone: exploratory time-series analysis of archaeological records. Chungara, Revista de Antropología Chilena 40, 245-259.

Zolezzi, M., 1993. Historia De Los Puertos Guaneros Del Litoral De Tarapacá (Hasta 1879). Centro de Investigación de la Realidad del Norte, Iquique.

Zori, C., Brant, E., 2012. Managing the risk of climatic variability in late prehistoric northern Chile. J. Anthropol. Archaeol. 31, 403-421.

Zori, C., Tropper, P., Scott, D., 2013. Copper production in late prehispanic northern Chile. J. Archaeol. Sci. 40, 1165-1175.

Zori, C.M., Tropper, P., 2010. Late pre-hispanic and early colonial silver production in the quebrada de Tarapacá, northern Chile. Boletín del Museo Chileno de Arte Precolombino 15, 65-87.

Zori, C.M., Tropper, P., 2013. Silver lining: evidence for Inka silver refining in northern Chile. J. Archaeol. Sci. 40, 3282-3292. 